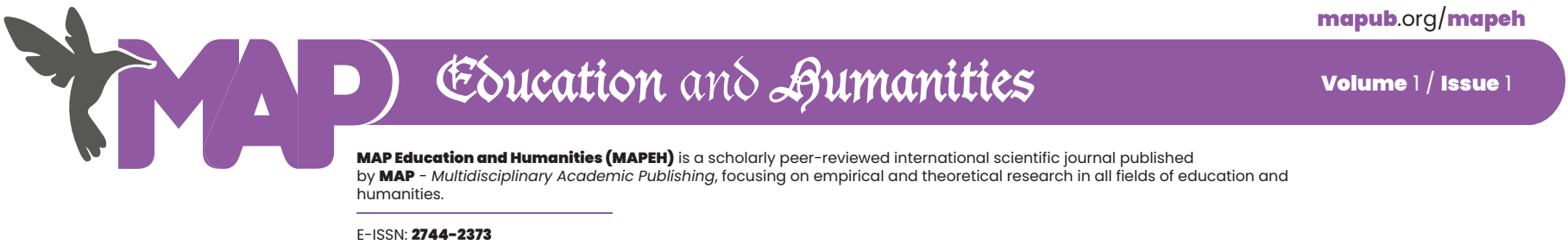

ORIGINAL RESEARCH PAPER

\title{
INITIAL P4C IMPLEMENTATION IN THE BOSNIAN AND HERZEGOVINIAN EDUCATIONAL CONTEXT
}

\author{
Remzija Hurič-Bećirovič' (1) , Mubina Muftič² (i) \\ First Bosniak Gymnasium, Cambridge International School, Sarajevo, Bosnia and Herzegovina \\ ${ }^{2}$ Vareš Majdan Elementary School, Vareš, Bosnia and Herzegovina \\ Correspondence concerning this article should be addressed to Remzija Hurić-Bećirović First \\ Bosniak Gymnasium, Cambridge International School, Sarajevo, Bosnia and Herzegovina, E-mail: \\ remzija.huric-becirovic@bosnjackagim.edu.ba and Mubina Muftić, Vareš Majdan Elementary \\ School, Vareš, Bosnia and Herzegovina, E-mail: mubinamuftic@gmail.com.
}

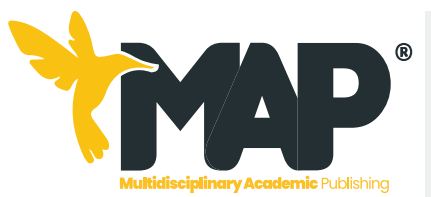

MAP EDUCATION AND HUMANITIES

Volume 1 / Issue

ISSN: 2744-2373/ ๔ 2021 The Authors. Published by MAP - Multidisciplinary Academic Publishing.

Article Submitted: 15 May 202 Article Accepted: 01 July 202 Article Published: 20 August 202

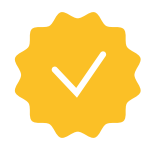

Publisher's Note: MAP stays neutral with egard to jurisdictional claims in published maps and institutional affiliations.

\section{ABSTRACT}

Bosnia and Herzegovina $(\mathrm{B} \& \mathrm{H})$ has a fragmented education system which is resistant to progressive changes. Therefore, implementing a program such as the Philosophy for Children (P4C) may make a significant impact on the lives of students and their teachers. In this paper, we discuss some potential benefits of the program and anecdotal evidence of its efficacy in two B\&H schools. The TPO Foundation, an NGO from Sarajevo -Transcultural Psychosocial Educational Foundation (TPO Fondacija, Equal opportunities and freedom of choice without discrimination on any ground), which has organized the first training in $\mathrm{P} 4 \mathrm{C}$ for teachers from several cantons in $\mathrm{B} \& \mathrm{H}$, is working on creating a framework for initiating the implementation of philosophy for children in cantonal education systems in the Federation of Bosnia and Herzegovina. This paper includes two cases of the implementation of P4C in two schools, through school courses, namely Religious Studies and English Language. The results of the study showed the program is very interesting to students and has a potential to improve school effectiveness in multiple ways. The findings of this study may help instructors to plan and organize their classes to acquire educational objectives in good and productive classroom atmosphere.

Keywords: philosophy for children, P4C, community of inquiry, B\&H education 


\section{esoucation and doumantities \\ by MAP - Multidisciplinary Academic Publishing}

INITIAL PAC IMPLEMENTATION IN THE BOSNIAN AND HERZEGOVINIAN EDUCATIONAL CONTEXT

Remzija Hurić-Bećirović and Mubina Muftić

\section{Introduction}

Philosophy for Children is part of a curriculum for 6- to 16-year-olds, even though it can be used with older students in secondary school, as it was intended by its developer Professor Matthew Lipman and his associates at the IAPC (Institute for the Advancement of Philosophy for Children) at Montclair State University, New Jersey. Lipman was born in Vineland, New Jersey, on 24 August 1923, into a Russian Jewish emigre community. Lipman first came to philosophy during the Second World War when he happened to be given a couple of books on the philosophy of John Dewey by an academic at Stanford University, where he studied for two terms as part of his induction into the army (Cam, 2013).

Lipman's project, conceived at Columbia University in the late 1960s in the wake of student unrest, was to encourage young people to be more reasonable: ready to reason and be reasoned with (SAPERE Handbook to accompany the Level 1 P4C Foundation Course, 2016). Students with serious behavioral issues are a challenge for their teachers (Mas `ić, Polz \& Bećirović, 2020); however, the concept of P4C promises to be a great and successful way of approaching these students in order for them to be able to acquire useful skills and feel more valuable in society. The spirit of the community of inquiry, which was a new model of learning (Communities of Inquiry) fosters collaborative thinking, caring thinking, creative thinking and critical thinking (4Cs). The phrase "Community of Inquiry" was actually coined by the American philosopher Charles Peirce to describe the community of scientists to which he belonged. Lipman gave the phrase a new meaning and life by pointing it in the direction of philosophical enquiry. He was also influenced by the idea of John Dewey.

Lipman emphasized the importance of questioning or inquiry in the development of reasoning. His idea is that "we learn to think much as we learn to speak" (SAPERE Handbook to accompany the Level I P4C Foundation Course, 2016, pp. 8), which means that we "borrow" language, i.e., ideas from others, without being aware of any underlying assumptions. During inquiry sessions, when a teacher asks students to explain their answers and to give the best reasons for them, it is not easy for some students to do that at the beginning. Through sessions of P4C they will listen to other participants, think more about their reasons, and sometimes they will be open to other students' ideas and develop their own thinking, while some of them will change their initial opinion through the P4C concept.

Communities of Inquiry, in which teachers and children collaborate with each other to reach a better understanding (Bećirović, Brdarević-Čeljo \& Zavrl, 2019), not only of the material world, but also of the personal and ethical world around them, is a useful method in workshops with students to discuss everything they really want to discuss and not uncritically follow the curriculum. Additionally, this collaboration gives an opportunity to students to be more open-minded, because their teacher is not the most important person in the room; instead, everyone is a valid contributor. Lipman accepted and further developed John Dewey's idea of a community which "can best serve the citizens of an ever-changing world". This idea of a community of inquiry and a world which changes for the better should be more developed not only through P4C in classrooms but also through everyday life.

\section{P4C Principles: A tool for teaching and learning dialogical critical thinking in a democracy}

In an inquiry, it is very important to focus on improving questioning in order to develop reasoning and reflection, and these bring into play, among other things, emotions and thoughtful expressions of emotions (Rizvić \& Bećirović, 2017). It encourages open-mindedness and creates conditions for change, both for individuals and for communities.

Inquiry and reflections or dialogue may be exercised in almost any learning context (Delić \& Bećirović, 2016), however P4C has a specific framework of action. Alternative names, especially when educators work with primary school children, include "thinking circles" or "discussion lessons". It is strongly recommended that thse sessions of inquiry follow certain principles and procedures. Some principles of $\mathrm{P} 4 \mathrm{C}$ are:

- Respect for each person's interests and questions;

- Acknowledging that each person's experience is unique;

- No person is the all-knowing;

- Appreciation for different ways of interpreting and thinking. 


\section{esucation and doumantities \\ by MAP - Multidisciplinary Academic Publishing}

INITIAL P4C IMPLEMENTATION IN THE BOSNIAN AND HERZEGOVINIAN EDUCATIONAL CONTEXT

Remzija Hurić-Bećirović and Mubina Muftić

There are also certain ground rules, such as: Do not put each other down; Give each speaker time to finish; Listen carefully to each other; Give good reasons for your ideas and opinions; Carefully develop hypotheses, or possible solutions, to our questions; Look for assumptions that may be hidden in our questions or dialogue contributions. Principles of P4C may be presented as dispositions of virtues to be cultivated, such as: sincerity, openness, curiosity, tolerance, empathy. It is very important to add principles of truth and caring for others through thinking and acting.

The ten steps of any inquiry are: preparation, presentation of stimulus, thinking time, question-making, questions-airing, question-choosing, first words, middle words, last thoughts and reviewing (and planning). These sequences should be interpreted to participants through "SAPERE Handbook to accompany the Level 1 P4C Foundation Course" (2016, pp. 19-24) and "SAPERE Handbook to accompany the Level $2 A$ Course (2018, pp. 22-25). If students understand the basis of $\mathrm{P} 4 \mathrm{C}$, sessions will be more successful.

The development of thought in $\mathrm{P} 4 \mathrm{C}$ from critical dialogue to dialogical critical thinking revealed four thinking models:

1) Logical Thinking

2) Creative Thinking

3) Responsible Thinking

4) Meta-Cognitive Thinking (Daniel, 2007).

Firstly, teachers-facilitators should be welltrained in different models of thinking (Bećirović, Hodžić \& Čeljo, 2019), including these four: logical, creative, responsible and meta-cognitive thinking as a productive way of facilitating successful sessions of P4C with their students. Professor Lipman, as a founder of Philosophy for Children, is the author of the book Thinking in Education (2003), which has a paramount importance in helping develop thinking and inquiry in $\mathrm{P} 4 \mathrm{C}$ sessions.

Principles of P4C and the learning process of dialogical critical thinking are possible if facilitators follow the rules of democracy. Echeverria and Hannam (2016) wrote the chapter "The community of philosophical inquiry (P4C): a pedagogical proposal for advancing democracy." The aim of that chapter is to make a contribution to the educational debate about the democratic nature of the Community of Philosophical Inquiry (CPI) (Echeverria et al., 2016).
The core of qualitative $\mathrm{P} 4 \mathrm{C}$ is a good inquiry. Hannam, as an experienced SAPERE trainer (Bloomsbury.com, 2010) and professor who has been developing the ideas of P4C in Bosnia and Herzegovina with the TPO Foundation, has discussed inquiry in Religious Education. Hannam (2012) has identified two key reasons for advancing inquiry in Religious Education (RE). The first, drawing from John Dewey, is that inquiry itself is at the heart of good educational practice. The second reason relates to the fact that humankind is living in increasingly uncertain times and acknowledging that this has a great impact on the lives of young people who need to live meaningful lives. We can conclude that both reasons are significant for any proper inquiry and education.

Conclusively, P4C allows for a very useful way of thinking, understanding, finding reasons, discussing different topics, and it should be included in the educational system of Bosnia and Herzegovina.

\section{P4C in the B\&H educational context}

Philosophy for Children (P4C) is therefore quite an unconventional approach to teaching. From the outset, the education system in Bosnia and Herzegovina has been about rote learning (Magill, 2010), or at least accepting that the material taught by teachers is unquestionable and that it should be accepted as such, memorized for tests and exams and then most likely forgotten in favor of something much more interesting or relevant to one's daily existence. As a teacher trainee, one is expected to critically evaluate one's own educational experience before it is implemented as an internalized teaching approach. What one can quickly realize is that critical and empathetic teaching has been noticeably scarce (OSCE, 2012); a systematic topdown approach inhibits teachers' collective willingness to engage in progressive, self-critical and reflexive teaching.

The systems Bosnian and Herzegovinian children face are not just defective and complicated political systems but also largely patriarchal families, especially in rural areas (Bećirović, 2012; Meier, 2019), and business environments which are pathologically conductive to corruption (European Commission, 2019) and sexism (Gačanica, 2019). If young people are not given tools with which they can dismantle illusions of inevitability of things, they will be prisoners of the systems which make their lives unnecessarily difficult and stressful. P4C is one of those tools because it is not a set of rules that one memorizes only to disregard them when circum- 


\section{Eoveation and \&umanities \\ by MAP - Multidisciplinary Academic Publishing}

stances change. Being able to see different angles of the same issue and accept opposing views is a skill worth working on in this unpredictable day and age.

As P4C sessions with students' progress, the motivation of the teacher increases, fueled by positive responses of young children and teenagers to discuss questions on which they themselves agreed. P4C is a kind of Socrates' method of questioning with empathetic guidance: it is implicit philosophy that does not require knowing concrete philosophers' biographies, theories and conclusions. This approach allows children to explore the world on their own terms without the fear of being ridiculed for their lack of experience. It gives children agency in education by allowing them to question the truth in a textbook or those of their teacher. In P4C, truth is a very contentious subject because in principle one does not assume that an inquiry will end in a final and uncontended conclusion we may call "the truth".

For that reason, that basic feature of inquiry might be considered a stumbling block for those teachers who hold certain things to be unquestionably true, such as the belief in God or the authority of one's personal life lessons. Whatever one's beliefs or opinions may be, inquiry presupposes that we suspend our firm belief in them as we enter the classroom with an open mind. By doing so, one allows for other participants' perspectives to be seen and heard; the invisible sound wall that is created by deeming something to be unquestionable is then torn down, allowing room for dialogue. In postwar Bosnia and Herzegovina, after a conflict in which claims of religious superiority were abundantly used as an excuse to create so-called "purified territories", devoid of other religious and national groups, even the seemingly simple phrase of believing in God becomes extremely potent in underlying assumptions. For this society to find its path towards healing, it is of greatest importance to unpack such assumptions and see where they lead to and how they are often being abused.

The increasingly complex globalized world (Dubravac, Brdarević-Čeljo, \& Bećirović, 2018) demands that its citizens be able to question things in order to respond adequately to the never-before-faced challenges. With the threat of climate change, active engagement and cooperation stand out as key ingredients for the construction of a more optimistic view of its future. P4C is an opportunity for every child, adolescent and young adult to realize their potential power in contributing to a more compassionate society by training them- selves to see the other person's side as a default, especially at the time of crisis, which we also witness now. Lately, it appears that western countries have halted their immense progress in creating and maintaining an open society which made them into arguably the most desirable political aspiration for everybody else on the planet. Divisions, terrible miscommunication and outright tribalism is far from the 21st-century world people had envisioned in the new millennia.

Great literature and philosophy teach us that one must soldier on towards one's perceived light even in the grimmest of circumstances because the other options would be motivationally devastating. As a teacher in $B \& H$, it is not difficult to see what intricate networks of cynicism beset the youth in this country. Therefore, it is necessary to work on warding off the defeatist conformism of this society, and in that respect P4C can certainly become one of the more useful tools.

The plan of the TPO Foundation in Sarajevo is to train a group of teachers through P4C training, who will teach other educators in $B \& \mathrm{H}_{\text {, and }}$ to introduce the ideas of this philosophy into the curriculums of different cantons in FB\&H. If it succeeds, it is useful to follow the examples of the Republic of Slovenia and other countries, and introduce P4C as an optional subject in several grades of primary and later secondary school.

The first five-day SAPERE (Society for the Advancement of Philosophical Inquiry and Reflection in Education) TOT (training of trainers) with the P4C method was held in August in 2018 in Sarajevo. The trainer was Dr. Patricia Hannam, who works as an Education Advisor in the UK and is a longtime trainer at the SAPERE Institute. The participants were teachers from the following schools in Sarajevo and Zenica Canton: the Second Gymnasium in Sarajevo, the Third Gymnasium in Sarajevo, the First Bosniak Gymnasium in Sarajevo, the Franciscan Classical Gymnasium in Visoko, Vareš Majdan Elementary and Stranjani Elementary in Zenica. There were also representatives from the Faculty of Philosophy in Zenica and a representative of the Jewish Community of Sarajevo and members of the TPO Foundation. After the initial one, another three TOT sessions (each four-day long) were held with the same group of trainers who are now certified for each level of training with the SAPERE London Institute certification. All trainers conducted at least ten philosophical inquiries with children and students from 2018 to 2020 and simulations within the 


\section{esoucation and doumantities \\ by MAP - Multidisciplinary Academic Publishing}

INITIAL PAC IMPLEMENTATION IN THE BOSNIAN AND HERZEGOVINIAN EDUCATIONAL CONTEXT

Remzija Hurić-Bećirović and Mubina Muftić

TOT group, they wrote essays and reflections on key texts and took the final exam (TPO Fondacija, What is SAPERE B\&H).

\subsection{Initial P4C implementation in Case 1}

By working as a teacher of religious studies, confessional and non-confessional subjects, it is easy to include P4C lessons in teaching because almost all lessons, especially for students in higher grades, offer opportunities for practicing the 4Cs.

There are often many lessons in textbooks with interesting information about different or similar rules in e.g., monotheistic religions, lessons about morality, caring for others, places of worship, sacred writings, festivals, pilgrimages, denominations in religions, family etc. - all of which offer plenty of opportunity for discussion in inquiry sessions.

Our goal for $\mathrm{P} 4 \mathrm{C}$ in the near future, including class contexts and some challenges, is to work more extensively on implementing the active listening practice in our class, so that our students can translate it into their everyday lives, and to find ways to make collaborative and caring thinking a more prominent part of inquiries, especially creative thinking.

We find that many sessions that we had with our students were successful. We have realized that some students were more interested in inquiry sessions than others. Active listening and supporting one's opinion with valid arguments are two very important parts of inquiry which are underdeveloped in Bosnian and Herzegovinian education systems. We hope that ministries of education in $\mathrm{B} \& \mathrm{H}$ (at least in Sarajevo Canton) will recognize the paramount importance of P4C.

In our teaching and facilitating, every next session has produced better discussion and a complete adherence to the rules of P4C. We plan to further explain the concepts of P4C to our students with a presentation, a video-clip, a poster, cards, handbooks, with the idea in mind that we will practice being aware of these concepts and implementing them at each session. Personal opinions and their expressions are very important to our students.

\subsubsection{Philosophical dialogue - class inquiry session on the topic of marriage}

The class is made up of third-grade students (age 17). They have previously had two philosophical inquiry sessions (in the second semester) and are acquainted with the basic practical principles and rules of inquiry. They have also had two philosophical inquiry sessions in the first semester.

As a warm-up activity we told students to play one short game - exchange seats with one another. After the game, they explained in three words the term "marriage". At the end of the session, we had reminded them of some of the words from the beginning: love, communication, patience, compromise, trust, community, relationship, understanding, feeling, respect, common aspirations. After explaining the term "marriage", they seemed ready to try and write down some questions. The students came up with the following questions:

1. Is trust more important than love?

2. What are the consequences of the lack of trust in marriage?

3. Are marriages more successful when they are built on trust?

4. How to keep the trust?

Each student was allowed one vote by putting a tick on a question. We suggested that they could vote for their question, but that we would have preferred them not to. The question with the highest number of votes was: "Is trust more important than love?" All questions contained the term "trust".

Facilitator: You chose this question: Is trust more important than love? In all questions we have a term 'trust'. Could you tell us something about this question? Could you explain why you chose this question?

B. M.: We brought up this question by rephrasing the first one.

N. M.: Because love and trust equally matter.

Facilitator: When you hear what somebody said, you can take these cards such as: I agree, I disagree, I think... because, I partially agree...because. N. M. said that love and trust equally mattered. What do the others say? (Repeating the rules of inquiry)

Dž. Dž.: Yes, they do equally matter.

Facilitator: Why do you think that? 


\section{Eucation and doumanities \\ by MAP - Multidisciplinary Academic Publishing}

INITIAL PAC IMPLEMENTATION IN THE BOSNIAN AND HERZEGOVINIAN EDUCATIONAL CONTEXT

Remzija Hurić-Bećirović and Mubina Muftić

H. M.: Because love and trust should coexist in a relationship.

Facilitator: Anyone else who agrees with $\mathrm{H}$. M.? Here you go, A. N.!

A. N.: Me, because they are equally important. If one loves somebody but there is no trust, that relationship has no future.

L. B.: I agree. Love without trust is like a house without a roof. You have it, but it's not complete.

Facilitator: Well done. T. Š. agrees, too. Why?

T. Š.: Because one [love] cannot exist without the other [trust]. Both have to exist.

L. G.: I would say that trust is the foundation of where love originates, and that is mutual trust.

Facilitator: Now, I gave you some papers that may help you. Raise your hands and join the discussion. Yes, H. M.?

H. M.: Trust is more related to our mind, and love is more related to emotions, and these two have to be balanced.

Facilitator: Well said. Please, go on, B. M.

B. M.: There's one song that says that the line between love and hatred is very thin. I think love is easily destroyed if trust is broken.

Facilitator: Very smart of you to relate this topic to a song. There's one ayah in which Allah says that He placed affection and mercy between spouses. Yes, Dž. Dž.?

Dž. Dž.: A relationship is built on trust, not love. A relationship is firmer and love is built throughout the time.

Facilitator: What are the consequences of love being more important than love? Do you think that marriage can be built on trust, not love?

Dž. Dž.: Yes, because we can love someone, and not trust them.

L. B.: Well, at the beginning of every marriage and relationship there's love. After many years, trust has more value than love. It's not more important than the other, but in one moment it overtakes love.
L. G.: Love is irrational and it leads us in our relationships with the one we love. Love makes us curious, and it can sometimes take people in the wrong direction. In such cases, it is important to think of both objective and subjective aspects of the relationship, because love and trust themselves mean security.

H. M.: They [love and trust] are sometimes separate. But then, they are not equally important. Love can sometimes overtake trust and vice-versa.

Facilitator: Who agrees with H. M.? Here you go, N. M.!

N. M.: Well, I can trust someone who's my friend, but that doesn't mean that I am going to be in a relationship with them.

B. Č.: People usually get into relationships and marriage because of love, not trust.

Facilitator: Very smart thoughts! Let's have an applause for you!

B. Č.: Primarily [they get into relationships] because of love, and then love becomes less important, but trust grows as the two are together for a longer time. I think trust and respect are necessary for a relationship to exist for a longer time.

Facilitator: How to save that love?

A. N.: Sooner or later, the person who doesn't feel the love will be looking for it.

H. M.: I think trust is somehow limited, contrary to love which is endless. If trust is broken at the beginning of a relationship it takes a lot to be taken back, but love is infinite.

L. B.: Love is what makes us go into a relationship; of course, it should be maintained and strengthened.

Facilitator: So, it seems that love is infinite. Could you explain? There's no right or wrong answer.

H. M.: That's my opinion - love is loving somebody's traits of character. But when it comes to trust, either there is trust or there isn't.

L. B.: I want a reply to her [A. N.'s] statement that people will be looking for love, but when we are in our 20s or 30s, we will have the care, 


\section{esoucation and doumantities \\ by MAP - Multidisciplinary Academic Publishing}

INITIAL PAC IMPLEMENTATION IN THE BOSNIAN AND HERZEGOVINIAN EDUCATIONAL CONTEXT

Remzija Hurić-Bećirović and Mubina Muftić

but nobody is going to look for love in somebody else in their 60s.

T. Š.: Why do people cheat on their spouses in their 60s? Apparently, that person is feeling the lack of something in the relationship with their spouse and they're looking for it in somebody else.

A.N.: Yes, but these problems begin earlier, not in the 60s. It becomes a bit deeper - the lack of love might have been a struggle for these people for a much longer time.

Facilitator: That can last for a long time.

T. Š.: I wanted to add something on what $\mathrm{H}$. M. said about love being infinite. That implies that when we love someone, we will show our love for that person every day differently. We can surely have a lot of reasons to love them.

Facilitator: So, creativity matters as well. Next is I. D.

I.D.: At the beginning, Dž. Dž. said that trust is necessary for a good marriage and that love can be built later. I disagree because I think that love is necessary to form a marriage and that trust is built later. Love cannot be built, because it becomes more of a habit than love. With time, we'll see that our loved one is trustworthy and ready for communication. That is how trust is built and that's why I think love is more important for marriage.

L. G.: The first moment when we meet someone might be a result of love and our heart might lead us to that we like someone, and to wish we spent some time with them, but everything that comes after is the result of honesty and trust between two people. Love is the trigger; trust is what leads us later. In the end, we love someone because we trust them. And if it's the case that we trust somebody because we love them, I think that relationship at that point is on the wrong path.

A.N.: I agree with I. D. and I think that emotions are something that we can't build and what we cannot influence. After a long time, we still like the person and their character, and trust is only gained.

B. M.: I just wanted to say that after 60 years, it [love] depends on the person's mindset. We cannot expect from one person to always behave the same way with us, for example, at the beginning of a honeymoon and 60 years later. It is obvious that there will be oscillations in the relationship.

Facilitator: Why is it obvious that there will be oscillations? Love might not be expressed the same way, but still, the community should be built. People sometimes don't need a lot. A flower or a sweet gesture means a lot. Could you give an example?

L. B.: Love can be strengthened and built, and I think, just like A. N., that love is very abstract. I believe that it cannot be created or strengthened by everyday gestures. For example, if a husband gifts his wife more than often, she can get bored and we see where materialism comes from.

A.N.: The feeling of being with somebody matters.

L. G.: Yes, love changes throughout the time, it is impossible to expect that somebody loves us the same way like they used to because people change every day. Because we change, because we evolve, that's why love evolves into another type of love. After decades of marriage, it is not the feeling of being in love that makes the relationship. After that long time, many aspects make that relationship, from life philosophy to the most important community - family.

I.D.: I agree with L. G. because I think that a person loves someone even if they don't deserve it.

Facilitator: Why do they then love them?

I.D.: Because emotions cannot be controlled, for example, a woman may love her husband even if he isn't a good husband, but it is a question if she will stay and if that marriage will be healthy and stable.

Facilitator: Thank you. You mentioned emotions that cannot be controlled. Can you explain that?

L. B.: We cannot have an impact on whether we'll like somebody or not. We cannot have an impact on whether we'll love somebody or not. Maybe we don't like people like them at all, but our emotions and feelings are stronger than us and they win. 


\section{esoucation and doumanities \\ by MAP - Multidisciplinary Academic Publishing}

INITIAL PAC IMPLEMENTATION IN THE BOSNIAN AND HERZEGOVINIAN EDUCATIONAL CONTEXT

Remzija Hurić-Bećirović and Mubina Muftić

L. B.: I think we cannot control what we feel but we can control how we express our emotions.

A. $\mathbf{N}$. I I agree with them and I think that people in general realise that they are not for each other and that they are missing something, after that first spark that can be deceiving.

Facilitator: Raise your hand who thinks that we are close to our answer. Take a better look at this paper and let's proceed to discussion if trust is more important or is there something else more important?

\section{B.: Mutual respect.}

Facilitator: Are there any other opinions?

I. D.: Whatever we say, it may not be for some people. Every person takes a different stance on marriage and friendship and it varies.

Facilitator: How good is that [what I. D. said] for the marriage?

A.N.: Yes, we are not all the same people and we differ. Marriage cannot be made with a pattern.

N. M.: We cannot determine if it's good or bad, it doesn't mean that somebody is going to feel good in their marriage because people sometimes don't agree on some aspects of their lives.

Facilitator: Many people start building their marriage by observing other marriages. That is often unrealistic and people are unhappy with everything they want to have, such as travelling or something else, but their spouses cannot afford that.

Dž. Dž.: I think A. N. or I. D. said what I wanted to say. We, as human beings, think differently. Marriage cannot be a pattern.

H. M.: To conclude, it depends on everything; at the beginning, both love and trust matter and they should be constant.

L. G.: I think in both cases it is important to know that trust and love are built in a relationship that brings safety and comfort, just like tranquility, peace or wellbeing... Love and trust sound equally beautiful and comfortable, just like the words I mentioned later.
Facilitator: H. M., is that continuity possible?

A.N.: I think it's possible for love and trust to be continuous, and even if it's not, spouses should complement each other.

L. B.: If two people find each other and love each other, everything will succeed to feel the same love, respect and trust after 60 years, just like at the beginning.

B. M.: It is important for spouses to be "at the same wavelength", that is, to have different ways of expressing love and to understand each other.

Facilitator: In Islam, a term Kafa'ah is used to describe marital suitability and compatibility, that is, for spouses to be of similar status, although they don't have to be.

B. Č.: Love and trust should be proportional as much as possible, and if love fades, trust should weaken, too, and vice-versa.

I.D.: Is it possible for them to be continuous and proportional? I think not, because every marriage comes across obstacles, such as family issues, lack of trust and such. It is difficult to be constant when it comes to marriage and emotions.

A.N.: There are couples who express their love only by words, but that can become tiring and fake and it becomes a habit. It becomes monotonous and it loses its purpose.

Facilitator: Can we now proceed to our final thoughts? We could discuss this, but we don't have much time.

Dž. Dž.: I would like to ask only one more question: What if trust disappears or if love fades? What would the consequences be like? Or would they be the same?

A.N.: I think it's easier to renew love than trust.

H. B.: To conclude this question, both are important and marriage cannot exist without both of these. Both are important.

H. M.: I agree with A. N. I think trust is more important because it is easier to rebuild love.

Facilitator: Any other final thoughts? 


\section{Eoveation and Bumanities \\ by MAP - Multidisciplinary Academic Publishing}

INITIAL P4C IMPLEMENTATION IN THE BOSNIAN AND HERZEGOVINIAN EDUCATIONAL CONTEXT

Remzija Hurić-Bećirović and Mubina Muftić

H. B.: Trust and love depend on the personalities. Some people can control it, and for some people it won't be a success.

Facilitator: I would like to remind you of some of the words you wrote: love, communication, patience, compromise, love, community, relationship, understanding, feeling, respect, common aspirations, respect... Repeating words are love and respect. To those who wrote this: would you change something now? Would somebody like to share their opinion if it changed, or if it was strengthened? I heard a lot from you today. Thank you for sharing your opinions. I would like I. D. to arrange the cards. Choose a few cards. You may take them and this is our final exercise. We used the language of dialogue and we were discussing trust, marriage and love.

I.D.: On this card it says that we gave reasons and explained our ideas - I think we did so.

B. M.: We listened to each other.

I.D.: We stayed focused on the questions.

H. B: We gave an opportunity for everyone to speak.

H. M.: We used dialogue and had interactions with each other and the teacher.

\section{B.: We talked about different ideas.}

Dž. Dž.: For ideas, we gave examples and we explained them.

Facilitator: This is the end. Thank you and good luck!

The facilitator gave questions on which all students in the classroom may respond; there were a lot of big ideas in the questions, possibility of broad answers and creativity, too - which are important for P4C. The facilitator tried to give more material with new questions for deeper and more productive inquiry with the intention of getting closer to an answer to the main question.

The lack of active listening is a big problem. As this group's facilitator, we could have been more aware that there was a lack of active listening and should have prompted the students to offer examples for their opinions and to listen to others, in order for them to be able to either agree or disagree. We were able to emphasize the core of the stu- dents' statement and repeat them for others, but there was a strong need for everyone in the class to offer their opinions immediately, which is something we need to learn to handle more effectively, even though we have used the following method, i.e., to write on the blackboard in which order are the students going to respond. Listening to others is something that is sometimes even a problem for facilitators, especially when they have four or more lessons with other students before the session. Some students do not want to share their opinions and they have had to explain that there is no wrong answer (for some questions) and after this explanation they shared their own opinion more freely.

\subsection{Initial P4C implementation in Case 2}

Being an English teacher, it is possible for us to integrate P4C inquiries in our teaching because there are numerous lessons especially for higher grades which offer opportunities for practicing the $4 \mathrm{Cs}$. There are often "culture corners" in the textbook with interesting information about world cultures and/or Anglophone cultures with topics such as lifestyle, customs, behaviors, and cultural openness. In the textbook "Challenges 4" (Harris et al., 2010), there are modules such as the media, environment, imagination, fashion and looks that have to be taught and they have enormous potential for inquiry.

Similar to Case 1 situation, we find that our students and we need to additionally work on implementing active listening practices and to find ways to make collaborative and caring thinking a more prominent part of inquiries. We plan on choosing two to three classes where we would hold inquiries on a regular basis (twice a month). With a continuous implementation of active listening and supporting one's opinion with arguments, we believe that significant progress can be made. Furthermore, if inquiries become part of the annual plan which is submitted at the start of the academic year, there is room for the teacher to operate without pressure or fear of failing to meet the standard goals for one's subject.

Key concepts of P4C can be better presented to primary school students through a PowerPoint presentation and a poster, which can also serve as a tool for later self-reflection. By implementing inquiries in a higher grade (14-15 years old) and a lower grade (9-10 years old), we can make comparative progress and take notes on which methods, warm-ups, topics, voting options etc. work better for each age group. 


\section{esoucation and doumantities \\ by MAP - Multidisciplinary Academic Publishing}

INITIAL PAC IMPLEMENTATION IN THE BOSNIAN AND HERZEGOVINIAN EDUCATIONAL CONTEXT

Remzija Hurić-Bećirović and Mubina Muftić

\subsubsection{Philosophical dialogue - class inquiry session on the topic of respect}

The class is made of $4^{\text {th }}$ and $5^{\text {th }}$-grade students (ages 9-11). They have previously had two philosophical inquiry sessions and are acquainted with the basic practical principles of inquiry. As a

warm-up activity, we wrote down three unfinished sentences on the blackboard:

1. Respect is...

2. I respect those who...

3. I don't respect those who...

Students were asked to give their ending to these sentences before they attempt to form questions on the topic. After a brief discussion of their particular choices for each of the sentences, they seemed ready to try and write down some questions. The students came up with the following questions:

1. Should older people respect younger people?

2. Should we respect those who threaten us?

3. If parents don't take care of us, should we respect them?

4. How to earn respect?

5. Who deserves respect?

6. Should we respect those who don't respect us?

Each student was allowed one vote. We were wrong not to prohibit students from voting for their own questions because there were students who found the voting to be a kind of a game where they could win if their question was chosen by others. The question with the highest number of votes was: "Should we respect those who threaten us?", closely followed by: "Should older people respect younger people?"

Facilitator: You chose this question: "Should we respect those who threaten us?" Another question with a high number of votes was: "Should older people respect younger people?" We can focus on either one of these.

A. B.: I think older people should respect us, just like we respect them, when we go to the shop for them, they should at least say "Thank you".

A. D.: I agree with A. B.
Facilitator: You also think older people should respect you.

E. A.: I want to say something about the first question (Should we respect those who threaten us?) I think we shouldn't respect them: they are threatening us, why should we respect them?

Facilitator: But you might do what they tell you, even though you don't respect them.

E. A.: Yes.

D. R.: I think we shouldn't respect those who threaten us. Just because they could do whatever they like we should respect them?!

Facilitator: Have you ever been in a situation like that? Were you ever bullied?

D. R.: Yes, by a girl M. She laughed at my surname and bit me.

Facilitator: And that's of course why you can't respect her.

D. R: Of course not.

B. M.: I want to say something about the second question (Should older people respect younger people?) Older people think just because they are older, they can tell us what to do. I have a sister and we work things out together; for example, I go to the shop one day and then she goes the next day.

Facilitator: So, she has earned your respect. If she were behaving differently towards you, you wouldn't respect her.

A.R.: I have an example! Just the other day, an older woman in my building threatened me because my ball ended up on her balcony. I don't respect her because she yelled at me and threatened me even though I asked nicely for my ball back.

Facilitator: You are agreeing with B. M., "Just because you are older it doesn't mean youdeserve my respect".

E. A.: I agree with D. R. How can you respect people who were bad to you, who did bad things to you? I have the same example as D. R. The girl M. behaves terribly towards me, but she hasn't bit me yet. 


\section{Eucation and dimantities \\ by MAP - Multidisciplinary Academic Publishing}

Facilitator: Does that mean that you will fight with her more often because you don't respect her?

E. A.: Yes, she has said many horrible things to me in these four years that we have been in class together.

\section{E. T.: But how do we earn respect?}

Facilitator: We talked about what respect means to you. Here on the blackboard, you said that respect is: when you help someone, when somebody takes care of us, when somebody respects your privacy... if you do these things, you could earn somebody's respect.

This inquiry was predominantly based on sharing personal opinions, sometimes backed with explanations and examples. There is still much room for development of other types of thinking, starting with collaborative thinking. The facilitator should have taken control in this area and insisted on repeating others' opinions and offering more concise explanations of their opinions.

As this group's facilitator, we could have been more aware that there is a lack of active listening and should have prompted the students to listen to others to be able to either agree or disagree. We were able to emphasize the gist of the students' statements and repeat them for others to bear in mind, but there was a strong need for everyone in the class to offer their opinions instantaneously, which is something we need to learn to handle more effectively.

\section{Conclusion}

Philosophy for children (P4C) is an innovative way to include children into the flows of life irrespective of their age by allowing them to express their opinions and have their opinions heard. Inquiry facilitators have an important task of helping create an emotionally secure environment where children and adolescents can share their points of view. However, P4C is not intended to simply open up space for everyone to say something without evaluating the process which led them to certain conclusions, which may be immensely valuable for their being in this world.

Children and adolescents in Bosnia and Herzegovina definitely have much to contribute during inquiry sessions (Kovačević, Brdarević-Čeljo \&
Bećirović, 2018), but their patience for others and ability to empathetically and critically listen to each other is seriously underdeveloped; however, this pervading trait is possibly a reflection of the greater $\mathrm{B} \& \mathrm{H}$ society because it is difficult to listen to different voices and opinions which are not aligned with what we are accustomed to. While social media and the internet as a whole now allow like-minded people to communicate easily, excluding those with differing opinions can create an isolation bubble where attention is paid only to those people, news, and events which one finds agreeable.

If there is a will for change in order to reduce miscommunication and loneliness and increase emotional understanding, it is imperative to allow young people to recognize the erring modes of existence which have been perpetuated so far in the Bosnian and Herzegovinian society. In a society in which younger voices used to be silenced because of their "inexperience", we have come to the point where a tenuous scaffold is needed in a pursuit of truth in order to avoid a chaos of opinion output. P4C allows children and adolescents of all ages to collaborate in order to explore the whys of some aspects of contemporary life. 


\section{Eoveation and Bumanities \\ by MAP - Multidisciplinary Academic Publishing}

INITIAL PAC IMPLEMENTATION IN THE BOSNIAN AND HERZEGOVINIAN EDUCATIONAL CONTEXT

Remzija Hurić-Bećirović and Mubina Muftić

\section{References}

Bećirović S., Brdarević-Čeljo, A. \& Zavrl, I. (2019). Research into intercultural effectiveness in a multicultural educational milieu in Bosnia and Herzegovina. Economic Research-Ekonomska Istraživanja, 32(1), 1336-1351. doi: 10.1080/1331677X.2019.1629329

Bećirović, S., Hodžić, F., \& Brdarević-Čeljo, A. (2019). Critical Thinking Development in the Milieu of High School Education. European Journal of Contemporary Education, 8(3), 469-482. http://dx.doi. org/10.13187/ejced.2019.3.469

Bećirović, S., (2012). The Role of Intercultural Education in Fostering Cross-Cultural Understanding. Epiphany Journal of Transdisciplinary Studies, 5(1), 138-156. DOI: 10.21533/epiphany.v5il.49

Bloomsbury.com. (2010). Patricia Hannam. Bloomsbury. https://www.bloomsbury.com/author/ patricia-hannam.

Cam, P. (2013). Matthew Lipman (19232010). Diogenes, 58(4), 116-118. https://doi. org/10.1177/0392192112462202

Daniel, M.-F. (2007). Epistemological and Educational Presuppositions of P4C: From Critical Dialogue to Dialogical Critical Thinking. Gifted Education International, 22(2-3), 135-147. https://doi. org/10.1177/026142940702200305

Ćurko, B., \& Kragić, I. (2008). Filozofija za djecu - primjer "Male filozofije”. ŽıVOT I ŠKOLA: Časopis Za Teoriju i Praksu Odgoja i Obrazovanja, 54(20), 61-68.

Daniel, M.-F. (2007). Epistemological and Educational Presuppositions of P4C: From Critical Dialogue to Dialogical Critical Thinking. Gifted Education International, 22(2-3), 135-147. https://doi. org/10.1177/026142940702200305

Delić, H. \& Bećirović, S. (2016). Socratic Method as an Approach to Teaching. European Researcher, $111(10), 511-517$. doi: 10.13187/er.2016.111.511

Dubravac, V., Brdarević-Čeljo, A., \& Bećirović, S. (2018) The English of Bosnia and Herzegovina. World Englishes, 37(4), 635-652. HTTPS://DOI.ORG/10.1111/ WENG.12347
Echeverria, E., \& Hannam, P. (2016). The community of philosophical inquiry (P4C): a pedagogical proposal for advancing democracy. In M. R. Gregory, J. Haynes, \& K. Murris (Eds.), The Routledge international handbook of philosophy for children, (pp. 3-10). Routledge.

European Commission. (2019, April 11). Commission Staff Working Document: Economic Reform Programme of Bosnia and Herzegovina (2019-2021). Brussels; European Commission.

Gačanica, L. (2019). Gender-based Discrimination and Labour in Bosnia and Herzegovina. Helsinki Citizens' Assembly, Banja Luka.

Hannam, P. (2012). P4C in Religious Education. In L. Lewis \& N. Chandley (Eds.), Philosophy for children through the secondary curriculum, (pp. 127145). Continuum International Pub. Group.

Harris, M., Mower, D., \& Mešić, A. (2010). Challenges: engleski jezik za 8. razred osnovne škole: udžbenik 4 (Ser. Challenges). Pearson Longman.

Kovačević, F., Brdarević-Čeljo, A., \& Bećirović, S., (2018). Opportunities and Challenges Facing Bosnian High-School EFL Learners, European $\mathrm{Re}^{-}$ searcher. Series A, 9(4), p. 298-306, doi: 10.13187/ er.2018.4.298

Lipman, M. (2011). Thinking in education. Cambridge University Press.

Magill, C. (2010). Education and fragility in Bosnia and Herzegovina (Ser. Education in emergencies and reconstruction). International Institute for Educational Planning.

Meier, L. (2019). Women's power in the strongholds of the Patriarchy. Heinrich-Böll-Stiftung. https://ba.boell.org/en/2019/03/18/womens-power-strongholds-patriarchy.

Mašić, A., Polz, E. \& Bećirović, S., (2020) The Relationship between Learning Styles, GPA, School Level and Gender. European Researcher. Series A, 11(1), 51-60. doi: 10.13187/er.2020.1.51

Rizvić E., \& Bećirović, S., (2017). Willingness to Communicate in English as a Foreign Language in Bosnian-Herzegovinian EFL Context. European Researcher, 8(3), 224-235. doi: 10.13187/er.2017.3.224 


\section{esucation and doumanities \\ by MAP - Multidisciplinary Academic Publishing}

INITIAL PAC IMPLEMENTATION IN THE BOSNIAN AND HERZEGOVINIAN EDUCATIONAL CONTEXT

Remzija Hurić-Bećirović and Mubina Muftić

OSCE. (2012). Curricular Reform Factsheet. Organization for Security and Co-operation in Europe.

SAPERE Handbook to accompany the Level 1 P4C Foundation Course. 5th edition, September 2016.

SAPERE Handbook to accompany the Level 2A Course (2018). P4C Advanced Course Level 2A. Advance your skills for higher quality enquiries and to support less-experienced colleagues. 3rd edition.

Sharp, A. M. (2014). The Other Dimension of Caring Thinking (with a new commentary by Phillip Cam). Journal of Philosophy in Schools, 1(1), 15-21. doi: http://doi.org/10.21913/jps.vli1.989

TPO Fondacija. (n.d.). Equal opportunities and freedom of choice without discrimination on any ground. TPO Foundation. http://www.tpo.ba/b/ OnamaEN.html.

TPO Fondacija. (n.d.). What is SAPERE B\&H. Thinkerica. https://thinkerica.ba/en/what-is-sapere-bh/. 